\title{
Analysing internet policy as a field of struggle
}

\section{Julia Pohle}

Berlin Social Science Center (WZB), Germany

\section{Maximilian Hösl}

Berlin Social Science Center (WZB), Germany

\section{Ronja Kniep}

Berlin Social Science Center (WZB), Germany

Published on 24 Jul 2016 | DOI: 10.14763/2016.3.412

\begin{abstract}
This essay proposes an analytical approach that conceptualises internet policy as a field of struggle which emerges through processes of discursive institutionalisation. By combining field theory and selected Science and Technology Studies (STS) concepts, the essay highlights the performative function of discourses in the field. It does so by showing how actors entered the policy field through the creation of expertise and regulatory competences and uncovers key conflicts that have shaped internet policy. Drawing on interviews and document analysis, the essay illustrates the proposed research approach via three selected examples which demonstrate how international discourses materialised in internet-related organisational structures and regulatory competences in German ministries.
\end{abstract}

Keywords: Internet policy, Policy field, Discourse, Institutionalisation

\section{Article information}

Received: 02 Mar 2016 Reviewed: 06 Apr 2016 Published: 24 Jul 2016

Licence: Creative Commons Attribution 3.0 Germany

Competing interests: The author has declared that no competing interests exist that have influenced the text.

URL: http://policyreview.info/articles/analysis/analysing-internet-policy-field-struggle

Citation: Pohle, J. \& Hösl, M. \& Kniep, R. (2016). Analysing internet policy as a field of struggle. Internet Policy Review, 5(3). https://doi.org/10.14763/2016.3.412

Disclaimer: The theoretical reflections and empirical findings presented in this essay emerged from the collective work of the Internet policy project group of the WZB Berlin Social Science Center. Therefore, the authors would like to highlight the contributions of Benjamin Bergemann, Jeanette Hofmann, Florian Irgmaier and Lena Ulbricht. 


\section{INTRODUCTION}

Over the last decade, it has become increasingly obvious that the internet and digital technology are changing modern societies in fundamental ways. They are undergoing an open-ended process of transformation that is gradually affecting all areas of social life, calling into question societies' normative and institutional underpinnings. On the national and international levels, public authorities started to respond to the new political challenges by developing new expertise and competences to understand the technical change and to adapt their regulatory repertoire. Likewise, in most parts of the world, the digital transformation results in a dynamic public discourse and an expanding network of non-governmental actors seeking to shape and assess the socio-technical changes and discuss corresponding policy options.

This short research essay proposes to analyse these new constellations of actors, issues and policies as an emerging policy field related to the internet. Rather than assessing them as loosely connected elements that form a fragmented mosaic, the policy field perspective allows us to view actors, issues, discourses, policies and regulatory competences that emerge around internet issues as interrelated. But what is the relation between the various actors in the field and how do these actors, through their interactions, link issues with institutional structures, expertise and regulatory responsibilities? Which are the discursive and institutional processes that contribute to the emergence and shape of the policy field? In order to answer these research questions, the essay proposes an analytical approach that draws on different relational and constructivist theories from the social sciences. Since processes in the field are often conflict-laden, this approach is based on the conceptualisation of policy fields as fields of struggle and aims to retrace how conflicting discourses and power struggles materialise in form of the institutional and regulatory structures of the policy field.

By combining field theory with conceptual tools from discourse and institutional theory as well as Science and Technology Studies (STS), the proposed qualitative and historical approach builds on and simultaneously informs research interested in the emergence of policy fields (Bergemann et al., 2016; Bernhard, 2011; Haunss, 2015; Knoke, 2004; Lynggaard, 2007; Massey \& Huitema, 2013)1, the role of discourse for institutional change (Schmidt, 2008; Phillips, Lawrence, \& Hardy, 2004) and the contribution of actors, discourses and material structures for social ordering (Flyverbom, 2010; Latour, 2010). After introducing the analytical approach on a conceptual level, the essay illustrates the analytical ideas via selected empirical examples from Germany, which provide insights into the interrelations of discourses, regulation and institutional structures during the early and more recent stages of field emergence. Due to space limitations, the empirical case studies can only give a fragmented assessment of the various processes that helped shape the material and discursive structures of the German internet policy field. Drawing on the analysis of organisational charts and interviews, the selected examples serve to illustrate the value of the conceptual ideas by identifying crucial discourses and core conflicts that have shaped the German internet policy field.

\section{INTERNET POLICY: AN EMERGENT POLICY FIELD}

Without a doubt, internet policy making can be considered an increasingly important political field of action at both the national and transnational level. On the one hand, policymakers, researchers and non-governmental organisations (NGOs) show a growing interest in better understanding internet-related problems and in building up relevant expertise.2 On the other 
hand, the ever growing amount of internet policy related documents, institutions and decisionmaking structures indicates that public authorities and non-state actors persistently seek to create competences and influence the new societal and technical developments. As a result, we can currently witness the emergence of a multifaceted ensemble of policies which, thanks to the shared reference to the internet, link issues that previously were not interrelated. This ensemble also involves a relatively fixed number of individual and collective actors and institutions which are interconnected through their 'common concerns' (Lynggaard, 2007, p.293), that is, their shared interest in internet-related questions. Collectively these policies, issues, actors and institutions form an emergent policy field related to the internet.

Although still in emergence, the internet policy field has already acquired a high degree of complexity and diversity. This is not least due to the tension between the inherently global nature of the internet infrastructure and the attempts to regulate public policy aspects on the national or regional level (Johnson \& Post, 1996). Since the 1990s, the technical coordination of the global internet infrastructures has become gradually institutionalised in transnational settings that often apply a multi-stakeholder governance approach, such as the Internet Corporation for Assigned Names and Numbers (ICANN) (Mueller, 2010). In contrast, the regulation of public policy issues related to the internet-such as data protection, competition, security, access and content control-is primarily coordinated and implemented by national or regional authorities (Drake, Cerf, \& Kleinwächter, 2016, pp.31ff).3

Yet internet policies and related responsibilities differ quite significantly from one country to another. Some countries, such as the United States, tend to leave internet rule-making primarily to the 'free market', while others, such as France, assign regulation more strictly to public authorities. While many developing countries still focus on basic access problems, others' policy approaches are shaped by discourses on cyber threats, counter-terrorism or child protection, for instance in the UK. Moreover, countries put forward different governance instruments, such as national commissions (e.g. the German Parliamentary Enquete Commission on Internet and Society) or charters of internet principles (e.g. the Brazilian Civil Rights Framework for the Internet).4 As a result, national differences regarding internet policymaking appear to be strongly influenced by the concrete constellations of actors, existing and newly created institutional structures and the influence of dominant discourses. To analyse the emergent internet policy field of one particular country or on the global level, we propose to study the interrelation of these different elements constituting a social field.

\section{INTERNET POLICY AS FIELD OF STRUGGLE}

The conceptualisation of policy fields as a specific category of social fields provides a useful heuristic for analysing policy fields in general and for understanding the nature and effects of internet policy in particular. On that account, this essay draws on sociological field theory as developed by Pierre Bourdieu (Bourdieu \& Wacquant, 1992) and the more recent work on strategic action fields by Neil Fligstein and Doug McAdam (2012). 5 Although the application of field theory to policy fields as social spaces where state actors and non-state actors interact requires a broader theoretical discussion (see for instance Bernhard, 2011; Hösl \& Reiberg, 2016), it is important to highlight the constitutive elements of fields and their implications for the analysis of internet policy: the relatively autonomous constellation of actors, the struggle over meaning making and the issues at stake.

Social fields, such as arts, sports or academia, are relatively autonomous spaces, composed of a 
specific constellation of actors with their own social rules (Bourdieu, 1991, pp. 25ff; Swartz, 1997, p. 126). In fields, '[...] actors take one another into account in their actions' (Fligstein \& McAdam, 2012, p. 28). A specific feature of policy fields is that they are a constellation of both state actors and non-state actors who negotiate and make sense of social problems in relation to each other. We can assume that both the degree of autonomy and the relationship of state-actors and non-state actors varies significantly between policy fields in different countries and between different policy fields within the same country. In Germany, for instance, the internet policy field is composed of a multitude of state and non-state actors, including a large community of internet activists6, $\mathrm{NGOs}_{7}$, academics, federal agencies8, business associations9, members of political parties who often define themselves as 'Netzpolitiker', and ministries-as our examples in this essay will highlight.

Like all social fields, policy fields are areas of both collaborative meaning making (Fligstein \& McAdam, 2012, pp. 46f) and struggle (Bourdieu \& Wacquant, L., 1992, pp.102ff). In other words, actors in a field are engaged in struggles over meaning making. In the internet policy field, the struggles concern the design of the technical infrastructure and the modes of regulating internet content and usage. But they also concern the definition of the internet's role for society, for instance its framing as a public good, as a disruptive force of innovation or as a sphere of risk that requires surveillance. Many have argued there is a certain logic of the internet, inherent in its technical characteristics (van Vugt, 2016, p.131): the idea that the global internet should be open, decentralised, non-hierarchical and accessible to all (e.g. Schulze, 2016). Yet, as David Clark argues, 'the character of the Internet as we experience it today is, in fact, contingent on key decisions made in the past by its designers, those who have invested in it, and those who have regulated it' (Clark, 2016, p.9). Indeed, what some consider as the internet's inherent logic has always been the subject of disputes, initially between a few technicians, the network pioneers (ibid., p. 12). With the increasing commercialisation and politicisation of the World Wide Web starting in the 1990s, more actors such as activists, governments, companies and users entered the game and modified the internet continuously (DeNardis, 2014, pp.15ff). This ongoing modification concerns both the internet's technical design and the interpretation of this design. Broadly speaking, whereas some actors define the design of an open and neutral network as 'inherently insecure', others consider it as 'inherently democratic'.

What occurs in a policy field cannot be reduced to the conflictual search for policy solutions to a given problem.1o Instead, the policy problem itself, the knowledge necessary to address it and its potential solutions are being continuously produced, negotiated and reshaped by the interaction between the field and its actors. Accordingly, concrete policy decisions also depend on the contested question of what is at stake in the field. Is it (cyber)security, innovation or the social value of an open and universally accessible global communication network? And who has the expertise and the regulatory competencies-similar to the Bourdieuian concept of capital-to influence policy options and their implementation? The struggles among actors over these competing interpretations, over the expertise and over related modes of regulation can be described as core conflicts of the internet policy field. They structure the field of internet policy and distinguish it from the struggles structuring other policy fields, for instance the field of environmental policies or security policies.

In sum, policy fields can be conceptualised as relatively autonomous and contested spaces in which state actors and non-state actors 'jointly but antagonistically' (Marres, 2007, p.773) engage in processes of meaning making, the production of expertise and the negotiation of policy options. In order to analyse how actors, issues and competences are interlinked and to identify the concrete processes through which actors become engaged in the field, this essay 
combines the field approach with the concept of discursive institutionalisation.

\section{THE INSTITUTIONALISATION OF DISCOURSE IN THE POLICY FIELD AND ITS MATERIALITY}

To identify the struggles that shape a policy field in an observable way, it is necessary to understand how actors build links between themselves and the policies, perceptions, expertise and regulatory competences that, through their interrelation, form the field and its structures. For this purpose, the analytical approach proposed in this essay combines the meso-level analysis inspired by field-theoretical approaches with a micro-level analysis focussing on discourses and their role for the emergence of the policy field. Inspired by interpretative approaches that emphasise the importance of discourse for policymaking and institution building, we understand discourses as the ensemble of ideas, narratives and definitions that attribute meaning to objects and phenomena and, by doing so, create and reproduce a certain worldview.11 Hence, discourses are not simply the result of meaning making and an expression of problem perceptions, they also actively influence them due to their productive and reproductive function (Milliken, 1999, p. 235).

The performative effect of a discourse is particularly strong if it affects the formal and informal institutions that define the context in and modes through which actors interact in a field (Schmidt \& Radaelli, 2004, p. 192).12 Institutions serve as external structures that set the rules of the field. They are constructed by and, at the same time, structure the discourses and interactions in the field.13 But not all discourses are eventually institutionalised and develop a performative effect on the field and its actors (Phillips et al., 2004, p.638). In a policy field as a contested space, the process of discourse institutionalisation involves struggles between competing actors and their discourses. As our empirical research will show, in the end, it is either one of the competing discourses or the conflict itself that is inscribed in and, thereby, (re)shapes the policy field.

Thus, to better understand how actors are linked to institutions through discourses, it is necessary to analyse which discourses become institutionalised and, thereby, produce and change the institutional structure of the field: 'If a discourse solidifies in particular institutional arrangements [...] then we speak of discourse institutionalization' (Hajer, 2005, p.303). In order to retrace, on the micro-level, these moments of discursive institutionalisation and assess their performative effects on the actors, perceptions and practices on the field-level, we borrow the concept of 'inscription' from STS.14 There, the term refers to a process through which engineers, inventors and designers embed their visions, ideas and discourses in the material structure of objects or technical artefacts (Akrich, 1994), like the internet's technical designers inscribed the principles of openness and de-centrality into the materiality of the network's structure. Similarly, these visions can also be inscribed into institutional structures that constitute the material foundations of a field, such as policy programmes, organisational units and regulatory competences, and are equally artefacts as they are produced and shaped by the field's actors. By inscribing discourses into the materiality of the policy field, actors link issues with perceptions, institutions and competences and, that way, fundamentally add to the processes of social ordering in the field.15

Through their inscription, discourses not only become part of the material world but also of actors' social practices; as a consequence, they are conducive to their own reproduction: 


\begin{abstract}
Objectified beliefs often become embedded in routines, forms, and documents, e.g. the types of classifications employed, and artifacts - tools, hardware, and machinery. We organize our material world in accordance with our mental categories, and the two become self-reinforcing. (Scott, 2014, p.149)
\end{abstract}

In this sense, materialisations are not pure representations of reality, they also transform and reproduce the discourses and conflicts embedded in them. They have a performative character and contribute to the exclusion of alternative worldviews. Accordingly, the inscription of discourses into documents, technologies or organisational structures can be seen as '[...] enactments of reality; they are means by which some things are made present and others absent, so that specific ontologies are performed into being and others made invisible' (Nimmo, 2011, p.114). Moreover, through their inscription, discourses reach a more stable form and develop more permanent effects on actors, their perceptions and interactions. That way, discursive institutionalisations contribute to the development of a field-specific logic (Bourdieu, 1996, pp.227f; Thornton, Ocasio, \& Lounsbury, 2012, p.148), just as the visions inscribed in the internet's technical characteristics determine its inherent logic.

\title{
RETRACING THE INSTITUTIONALISATION OF DISCOURSES AND COMPETENCES IN THE GERMAN INTERNET POLICY FIELD
}

As outlined above, policy fields contain a heterogeneous population of state actors (i.e. political parties, governments, ministries) and non-state actors (i.e. NGOs, private companies). Despite this wide range of actors, this essay takes a closer look at selected processes of institutionalisation of discourses and competences within German ministries, which for two main reasons are particularly useful for illustrating our analytical ideas.

First, federal and state ministries in Germany are important sites of production for political programmes, professional expertise and regulatory competences (Derlien, 1995, p.80). Organised according to the principle of departmental ministers (Ressortprinzip), ministries both shape and reflect particular perceptions of problems and the logics in the policy field for which the ministry is responsible. This is not only the case for a ministry as a whole (e.g. the Ministry of the Interior following the logics of security) but also for the different divisions within the ministries (e.g. the IT Division following a distinct logic of IT security). Second, although ministries produce discourses that shape the policy field through their competences and programmes, they are simultaneously responsive to public, professional and political debates. Thus, we often see that a certain discourse is taken up by a ministry, where it materialises and solidifies into organisational structures and regulatory competencies. It is through both these functions-the production of discourses and their inscription-that ministries link issues with competences and institutional structures and, hence, contribute to the emergence and shape of a policy field.

To develop a historical perspective on the emergence of the internet policy field in Germany, the empirical examples in this essay illustrate instances of institutionalisation of international discourses in ministerial structures and competences. They took place at different moments in 
time and in two different ministries, namely the Federal Ministry of the Interior and the Federal Ministry for Economic Affairs.16 Both of them are in charge of implementing the German Digital Agenda, a strategic policy programme adopted by the current government coalition in August 2014.17 To retrace the moments in which conflicts and discourses materialised in these two ministries, we draw on organisational charts and semi-structured interviews with senior officials of federal ministries. The analysis of organisational charts has allowed us to understand how ministries take up and frame new issues and structurally integrate them in light of their specific policy traditions and remit.18 The qualitative interviews help us to detect narratives that explain the findings gained from the organisational charts in more detail.19 Each empirical example addresses in a first step the inscription of a discourse, followed by the creation of material structures and their contribution to social ordering and, lastly, the inscription's further implications for the policy field.

\section{(A) THE INSTITUTIONALISATION OF THE INFORMATION SOCIETY DISCOURSE}

Like most other countries, Germany began to develop a political response to the internet and its societal impact in the early 1990s, when the discussion on the information society started to unfold on both the national and international level. The concept of 'information society' was commonly used as a metaphor to capture the importance of information for economic and societal progress. Accordingly, many countries and international organisations started to adopt information society policies designed to pave the way for the transition towards an information economy driven by digital technology.2o Despite their similarity, the various initiatives differed in their nuances, revealing a key conflict inherent in the policy debate on the information society-a conflict that has accompanied internet policy discussions ever since. It consisted in the struggle between those who wished to accomplish the transition towards an information society through market liberalisation and self-regulation of the private sector and those who argued in favour of a more regulatory approach, which would strengthen the role of public authorities in planning and coordinating this transition (see also Kubicek, Dutton, \& Williams, 1997; Moore, 1998).

The German government perceived the transition to the information society as a matter of necessity resulting from international pressures and from what the government considered an inevitable external development (Thorein, 1997, pp. 69f). Therefore, it decided to build up regulatory capacities to shape the transition, which led to the institutionalisation of the discourse on the information society. Indeed, the discourse was inscribed in the bureaucratic structure of the German public administration in form of a 'Working Group on the Information Society', created within the Federal Ministry for Economic Affairs in 1995.21 The ministry's Division for Industry Policy developed the idea for this working group in the context of an internal debate reflecting the core conflict related to this early period of internet policies: as interviewees pointed out, there was a sense of anxiety in the ministry that too much regulation might be a barrier to the expected positive effects of the information society. Hence, many traditionalist actors in the ministry claimed that the existing competition policy was a sufficient regulatory frame for the digital age, whereas others argued in favour of a dedicated strategy for the information society in form of an industry policy.22 As the then Minister for Economic Affairs, Günter Rexrodt ${ }_{23}$, saw both positions as equally important, there was high-level support for both sides. Thus, the constellation within the ministry was favourable for the institutionalisation of the information society discourse.

Among other tasks, the new working group was responsible for the development of an influential strategy paper on the information society, called 'Info 2000' (BMWi, 1996; Thorein, 
1997, pp.58ff) 24 , which institutionalised both the dominant discourse on economic progress and the core conflict between market liberalisation and a stronger regulatory approach. It expressed the idea that governance instruments like data protection and labour law should be adapted to the requirements of the information society (Thorein, 1997, p.70) and the view that laws concerning the protection of consumers, data, youth, and others are not values per se but simply means to increase the acceptance and usage of the internet (Scholz, 2004, p.71). That way, the inscription of the information society discourse in the ministry led not only to its materialisation in form of a newly created organisational structure; it also materialised in form of an important policy text and thus contributed to the ministry's and its actors' effort to shape Germany's response to the new technological developments.

The performative effect of the materialisation of the information society discourse did not remain limited to the Ministry for Economic Affairs alone. Indeed, the 'Info 200o' paper served as one of the major reference points for the 'Multimedia Act', which was adopted in 1997 (Bundesregierung, 1997) and constituted the first German law accounting for the technological developments of the early 1990 s in a holistic way. The working group was the first impetus in the Federal Ministry for Economic Affairs to produce expertise and regulatory competencies for the new policy questions related to the growing importance of digital technology. By inscribing the information society discourse, the ministry created a first material link between the economic issues, the internet and itself. It thereby shaped the structures of the new policy field and inscribed its own role in a strategic and solid way, with the result that today, in 2016, the competencies of the former working group are part of a proper Division for Digital and Innovation Policy, which is responsible for most economy-related parts of Germany's Digital Agenda.

\section{(B) THE INSTITUTIONALISATION OF THE IT SECURITY DISCOURSE}

Some years after the initial institutionalisation of the information society discourse within the German administration, we can observe the inscription of a second discourse that eventually shaped regulatory competences for internet policy, this time created by the Ministry of the Interior. At the turn of the millennium, two major IT-related security issues raised public attention for the risks of technological development. The first issue was related to the change of date from ' 99 to 'oo that was feared to cause dramatic failures in IT systems (known as 'Y2K bug'), potentially affecting almost every aspect of social, economic and political life, including healthcare, financial markets and nuclear power (Special Committee 2000, 1999).25 The second security issue consisted of the computer virus named 'ILOVEYOU', a bug hidden in a fake love letter that spread via e-mail, affecting millions of computers within a few days.

The Y2K bug and the ILOVEYOU virus were not simply technical problems that had to be dealt with. Rather, they were discursive events which, in the ministry and beyond, led to a new level of awareness of how much the state's capacity to act was dependent on global IT infrastructure. According to some interviewees, both these events were major triggers for the decision of the German Ministry of the Interior to concentrate all IT-related competencies in a single unit, the IT Staff (German: IT-Stab), which was created in 2002.26 The IT security discourse materialised in the ministry's organisational structure through the creation of the new unit.27 In the following six years, the IT Staff developed from a unit outside the regular organisational hierarchy into a proper division. Named 'Division for IT and Cyber Security' since 2014, it bears responsibility for the Ministry of Interior's stake in implementing the German Digital Agenda. Thus, through the early inscription, the ministry not only linked internet and security issues in a stable way. It also institutionalised its own role and competence in the emerging policy field. 
One particular decision concerning the IT Staff's design in 2002 illustrates how the way in which the security discourse was institutionalised shaped the further development of internet policy within the Ministry of the Interior. As an interviewee explained, the IT Staff's composition was guided by the idea to pool 'genuine IT topics' within a single unit. Yet, instead of regrouping all existing IT-related technical and regulatory competences, the ministerial officials decided that the IT competence of the security agencies (police, internal intelligence agencies) should remain within the Division for Public Security. This organisational setting, characterised by a clear thematic distinction between general IT issues and the IT competence of the security agencies, contributed to institutionalising a conflict in the ministry which remains central to the internet policy field until today: the conflict between the protection of IT systems, on the one hand, and the possibility for security agencies to intrude into these systems, on the other hand.

The conflict between a preventive and repressive side of cybersecurity, as it was characterised by one interviewee, is in fact a variation of what is commonly described as the 'crypto debate'.28 For more than ten years, this conflict has been the subject of ongoing internal debates between two divisions of the ministry, the Division for IT and Cyber Security and the Division for Public Security. At the same time, the controversy over the protection (e.g. by encryption) and intrusion of internet communication (e.g. through spyware) has linked bureaucrats, security officials, politicians, and activists who are jointly but antagonistically engaged in the internet policy field.29 Thus, the inscription of the IT-security discourse in the ministry not only structured its own perception of internet policy but had a long-lasting influence on the larger debate and, hence, on the processes of social ordering in the field in general.

\section{(C) THE INSTITUTIONALISATION OF THE POLITICAL DISCOURSE FOLLOWING THE SNOWDEN DISCLOSURES}

While the first two examples illustrate the discursive institutionalisations shaping the organisational structures of the emergent internet policy field in its early stage, the third example shows how actors altered or intensified the institutionalisation of discourses and conflicts in the field and, thereby, created new or strengthened existing links between issues and regulatory structures. This happened in the context of the political debate that followed the revelations by the former National Security Agency (NSA) subcontractor Edward Snowden in 2013 concerning the mass surveillance programmes of the US foreign intelligence service and its allies. The political discourse on illegitimate and uncontrollable data collection and surveillance that was triggered by the Snowden disclosures reflects the tension between the global nature of the internet and policy problems at the national level. However, our interviewees made clear that the disclosures were taken up and institutionalised in a selective manner by the two ministries under investigation. The Ministry of the Interior focused on the vulnerability of national infrastructures embedded in global communication networks and framed the intelligence practices revealed by Snowden as a problem of security. The Ministry of Economic Affairs, by contrast, highlighted the technological and economic dependency on other countries or regions, which it perceived as a question of primarily economic nature.

In the context of the Digital Agenda, which was adopted a year after the first revelations by Snowden in 2013, the Ministry of the Interior established two new units dealing with 'cyber issues': a unit responsible for 'IT and cyber security; secure information technology', which is part of the existing IT Division, and a unit concerned with the technical competence of Germany's internal security agencies and the prosecution of 'cybercrime' within the Division for Public Security. This expansion of 'cyber' competences through the establishment of two separate units in different divisions was accompanied by the introduction of an overarching management structure in the form of a director heading both units. This union at management 
level is remarkable since the IT Division and the Division for Public Security share an interest in digital technology but-as described above-in a confrontational manner. Whereas the IT Division is concerned with the protection of information systems, for instance through encryption, the Division for Public Security seeks to improve the capabilities of the security agencies to fight 'cybercrime'. The Snowden revelations and the increased awareness of 'cyber threats' related to terrorism increased the existing controversy and, following long internal discussions among the ministerial staff, materialised in additional competencies for both protection and intrusion. As indicated by interviewees, the appointment of a joint director reflected the need for better coordination and mediation.

The disclosure of the surveillance programmes by the NSA and its partner services also intensified another debate which the Ministry for Economic Affairs inscribed into its institutional setting. Triggered by the increased perception of technological and economic dependencies on other countries and foreign companies in the IT sector that followed the Snowden revelations, a debate emerged regarding the trust in and security of IT infrastructures and applications. Politicians across Europe put forward solutions to this perceived problem that ranged from technical proposals like localised routing to measures fostering national IT sectors and were often summarised under the term 'technological sovereignty' (Maurer, Morgus, Skierka, \& Hohmann, 2013, pp.28f). The core conflict embedded in this debate is the tension between striving for more control over information flows and protecting the 'free and open internet' and the global free flow of information (Maurer et al., p.4).

The term 'technological sovereignty' gained popularity in Germany as well, and the current German government inscribed it into its 2013 coalition agreement (CDU, CSU, \& SPD, 2013, pp.103f.) and the 2014 Digital Agenda (BMWi, BMI, \& BMVI, 2014, p.4). Finally, it also materialised within the administrative structure of the Ministry for Economic Affairs. 30 According to an interviewee, the ministry saw the need to increase its capacities for issues often neglected due to the broad focus of the Digital Agenda. Therefore, in 2015, it established a new unit within the Division for Digital and Innovation Policy, which among other tasks is in charge of 'digital sovereignty'. With this move, the ministry not only inscribed the sovereignty discourse into its structure and thereby created a material and more permanent link between the conflict embedded in the discourse and its own competences. It also influenced the perception of policy problems and the production of expertise beyond its own institution as it linked economic, academic and administrative actors and key topics of digital sovereignty by developing a policy paper in cooperation with a group of experts (BMWi, 2015)..31 It thereby reinforced and shaped the debate on technological and economic dependencies in Germany.

\section{CONCLUSION}

This essay proposes an analytical approach which conceptualises internet policy as a field of struggle that emerges through processes of discursive institutionalisation. It identifies key conflicts and discourses that, thanks to their materialisation in the policy field, are able to link actors, issues and regulatory competences and, thereby, shape the field's structure in a temporary yet stable manner. For this purpose, we combine field theory and approaches focusing on discourse and institutions with STS tools, in particular the concept of 'inscription'. While the field approach serves to emphasise linkages and structures and to address their temporal stability on the field-level, the focus on discursive institutionalisations allows us to scrutinise the material traces left by inscriptions, for instance in form of organisational structures or policy papers. Hence, the conceptual combination makes it possible to evaluate the 
performative effect that the identified discourses and conflicts had on the policy field as a whole.

We illustrate this conceptual approach via three selected examples that show how international discourses related to the internet materialised in organisational structures in German ministries. The discourses on the information society of the early 1990 and IT security around the turn of the millennium were not transient debates that passed without leaving any traces. Instead, they created cognitive effects that translated into permanent structures within the Ministry for Economic Affairs and the Ministry of the Interior. These first materialisations were the starting point of a development that has led to proper divisions in charge of internet policy within both ministries, indicating that internet policy has grown into a relatively autonomous field of action within the German administration. The third example highlights how the two ministries selectively inscribed the political discourse following the Snowden revelations into their organisational structure, as the disclosures intensified existing debates in IT security and the call for more technological sovereignty. The examples show, on the one hand, how both ministries became actors in the emerging internet policy field through the discursive institutionalisations. On the other hand, they demonstrate how the ministries sought to position themselves within the field by shaping and reproducing field-relevant discourses and, thereby, influencing the field beyond their borders.

Furthermore, our analysis has identified two central conflicts and related struggles which have shaped the policy field's emergence and-in various facets-have structured many controversies in the internet policy field until today. Through the information society discourse, internet regulation became linked to the conflict between free-market liberal ideas and approaches that emphasise the need for dedicated political intervention. Besides the economic question of regulation versus liberalisation, the second example adds the institutionalisation of another, related core conflict to the map of the internet policy field: the conflict between the protection and the intrusion of digital communication. Both conflicts, as highlighted in the example related to the Snowden revelations, are connected to the tension between the internet as a global communication infrastructure and the attempts of actors to influence the internet through local regulation within the nation state. The conflicts' institutionalisation not only linked the related issues in a solid manner to the German internet policy field, it also created links between different actors in the field, as the ministries we investigated continuously engage with other state and non-state actors in the struggle over these core conflicts.

By combining the observation of the emergent policy field with the micro-level processes of discursive inscriptions, we gain insights into the materiality of the field that links actors, issues, expertise and regulatory competences. In addition, we are able to observe how actors seek to contribute to the processes of social ordering in the field that, ultimately, impact the autonomy and stability of the newly emerging policy field. In order to paint the larger picture and look at the policy field in its entirety, the proposed analysis would need to extend to other actors involved in the field, including non-state actors. Even more importantly, it needs to address the relation between these actors in a systematic way by retracing their linkages via shared or contested discourses and responsibilities. The identification of relevant conflicts and the initial analysis of relevant actors in this essay may provide a useful starting point in this respect. In addition, since in other countries the core conflicts might differ and materialise in other institutions, our future research will also assess processes of discursive institutionalisation in different countries to uncover the many interrelated yet often competing discourses, actors, issues and regulatory responsibilities that configure the internet policy field as a whole. 


\section{REFERENCES}

Akrich, M. (1994). The Description of Technical Objects. In W. E. Bijker \& J. Law (Eds.), Inside technology. Shaping technology/building society. Studies in sociotechnical change (pp.205-224). Cambridge, Mass.: MIT Press.

Bergemann, B., Hofmann, J., Hösl, M., Irgmaier, F., Kniep, R., \& Pohle, J. (Eds.). (2016). Entstehung von Politikfeldern - Vergleichende Perspektiven und Theoretisierung: Ergebnisse des Workshops am 25. November 2015. WZB Discussion Paper SP IV 2016-401. Retrieved from https://bibliothek.wzb.eu/pdf/2016/iv16-401.pdf

Bernhard, S. (2011). Beyond Constructivism: The Political Sociology of an EU Policy Field. International Political Sociology, 5, 426-445. doi: 10.1111/j.1749-5687.2011.00143.x

Bigo, D. (2011). Pierre Bourdieu and International Relations: Power of Practices, Practices of Power. International Political Sociology, 5, 225-258. doi: 10.1111/j.1749-5687.2011.00132.x

Bijker, W. E., \& Law, J. (Eds.). (1994). Inside technology. Shaping technology/building society: Studies in sociotechnical change. Cambridge, MA.: MIT Press.

Böcher, M., \& Töller, E. (Eds.). (2012). Reifung als taugliches Konzept zur Konzeptualisierung langfristigen Wandels von Politikfeldern? Überlegungen anhand des Politikfeldes Umweltpolitik. Paper presented at the 25th Conference of the German Association for Political Science (DVPW). Retrieved from

http://www.dvpw.de/fileadmin/docs/Kongress2012/Paperroom/2012Policy-B\%F6cher-T\%F6ll er.pdf

Bourdieu, P. (1996). The rules of art: Genesis and structure of the literary field. Stanford, CA: Stanford University Press.

Bourdieu, P. (1991). Language and Symbolic Power. Cambridge, United Kingdom: Polity Press.

Bourdieu, P., \& Wacquant, L. (1992). An invitation to reflexive sociology. Chicago, IL:

University of Chicago Press.

Braman, S. (Ed.). (2004). The emergent global information policy regime. Basingstoke, United Kingdom: Palgrave Macmillan.

Bund transparent: Parlament, Regierung, Bundesbehörden; Organisation, Gremien, Anschriften, Namen. (1995 - 2014). Bad Honnef, Germany: Bock.

BMWi (1996). Unterrichtung durch die Bundesregierung: Bericht der Bundesregierung Info 2000 - Deutschlands Weg in die Informationsgesellschaft. Bundesministerium für Wirtschaft. Drucksache 13/4000. Bonn, Germany.

BMWi. (2015). Leitplanken Digitaler Souveränität. Retrieved from BMWi website:

https://www.bmwi.de/BMWi/Redaktion/PDF/IT-Gipfel/it-gipfel-2015-

leitplanken-digitaler-souveraenitaet,property=pdf,bereich=bmwi2012,sprache=de,rwb=true.pdf

BMWi, BMI, \& BMVI. (2014). Digitale Agenda 2014 - 2017. Retrieved from

http://www.digitale-agenda.de/Content/DE/_Anlagen/2014/o8/2014-08-20-digitale-agenda.p $\mathrm{df}$ ?_blob=publicationFile\&v $=6$ 
Bundesregierung. (1996). Entwurf eines Gesetzes zur Regelung der Rahmenbedingungen für Informations- und Kommunikationsdienste (Informations- und KommunikationsdiensteGestetz - IuKDG). Drucksache 966/96. Retrieved from http://dipbt.bundestag.de/doc/brd/1996/D966+96.pdf

Callon, M. (1987). Society in the Making: The Study of Technology as a Tool for Sociological Analysis. In W. E. Bijker, T. P. Hughes, \& T. Pinch (Eds.), The Social Construction of Technological Systems (pp. 83-103). London, United Kingdom: MIT Press.

CDU, CSU, \& SPD. (2013). Deutschlands Zukunft gestalten: Koalitionsvertrag zwischen CDU, CSU und SPD. Retrieved from CDU website:

https://www.cdu.de/sites/default/files/media/dokumente/koalitionsvertrag.pdf

Clark, D. D. (2016). The Contingent Internet. Daedalus, 145(1), 9-17.

doi:10.1162/DAED_a_oo361

de Borchgrave, A., \& Lanz, S. (1999). Technology bites back. Forum for Applied Research and Public Policy, 14(2), 6-12.

de Maizière, T. (2010). Mitreden übers Internet: Perspektiven deutscher Netzpolitik: 14 Thesen zu den Grundlagen einer gemeinsamen Netzpolitik der Zukunft. Retrieved from BMI website: http://www.bmi.bund.de/cae/servlet/contentblob/1099988/publicationFile/88667/thesen_ne tzpolitik.pdf

DeNardis, L. (2014). The global war for Internet governance. New Haven, CT: Yale University Press.

Derlien, H.-U. (1995). Public administration in Germany:Political and societal relations. In J. Pierre (Ed.), Bureaucracy in the modern state. An introduction to comparative public administration (pp.64-91). Aldershot, United Kingdom: Edward Elgar.

Dobusch, L. (2014). Digitale Zivilgesellschaft in Deutschland: Stand und Perspektiven 2014 (School of Business and Economics Discussion Paper 07/2014). Retrieved from Free University of Berlin website:

http://edocs.fu-berlin.de/docs/servlets/MCRFileNodeServlet/FUDOCS_derivate_oooooooo3 411/discpaper2014_7.pdf

Drake, W. J., Cerf, V. G., \& Kleinwächter, W. (2016). Internet Fragmentation: An Overview (Future of the Internet Initiative White Paper). Retrieved from World Economic Forum website: http://www3.weforum.org/docs/WEF_FII_Internet_Fragmentation_An_Overview_2016.pdf

Fischer, F., \& Forester, J. (Eds.). (1993). The Argumentative Turn in Policy Analysis and Planning. Durham, NC: Duke University Press.

Fischer, F., \& Gottweis, H. (2012). The Argumentative Turn Revisited: Public Policy as Communicative Practice. Durham, N.C.: Duke University Press.

Fligstein, N., \& McAdam, D. (2012). A theory of fields. New York, NY: Oxford University Press.

Flyverbom, M. (2010). Hybrid networks and the global politics of the digital revolution - a practice-oriented, relational and agnostic approach. Global Networks, 10(3), 424-442.

http://doi.org/10.1111/j.1471-0374.2010.00296.x 
Gasper, D., \& Apthorpe, R. (1996). Introduction: Discourse Analysis and Policy Discourse. European Journal of Development Research, 8(1), 1-15.

Giacomello, G. (2008). National governments and control of the Internet: A digital challenge (2nd ed.). Routledge research in information technology and society. New York, NY: Routledge.

Graham, O. L. (1994). Losing time: The industrial policy debate. Cambridge, MA: Harvard University Press.

Hajer, M. (1993). Discourse Coalitions and the Institutionalization of Practice: The Case of Acid Rain in Britain. In F. Fischer \& J. Forester (Eds.), The Argumentative Turn in Policy Analysis and Planning (pp. 43-76). Durham, NC: Duke University Press.

Hajer, M. (2005). Coalitions, Practices, and Meaning in Environmental Politics: From Acid Rain to BSE. In D. Howarth \& J. Torfing (Eds.), Discourse Theory in European Politics: Identity, Policy and Governance (pp.297-315). Basingstoke, United Kingdom: Palgrave Macmillan.

Haunss, S. (Ed.). (2015). Entstehung und Wandel von Politikfeldern [Special section]. Der moderne Staat, 8(1), 3-112.

Hösl, M., \& Reiberg, A. (2016). Netzpolitik in statu nascendi: Eine Annäherung an Wegmarken der Politikfeldgenese. In M. Lemke \& G. Wiedemann (Eds.), Text Mining in den Sozialwissenschaften: Grundlagen und Anwendungen zwischen qualitativer und quantitativer Diskursanalyse (pp. 315-342). Wiesbaden, Germany: Springer VS.

Hustedt, T., \& Tiessen, J. (2006). Central government coordination in Denmark, Germany and Sweden: An institutional policy perspective (Regierungsorganisationen in Westeuropa Research Paper 2). Retrieved from University of Potsdam website: https://publishup.unipotsdam.de/frontdoor/index/index/docId/728Jochim, A. E., \& May, P. J. (2010). Beyond Subsystems: Policy Regimes and Governance. Policy Studies Journal, 38(2), 303-327.

Johnson, D. R., \& Post, D. (1996). Law and borders: The rise of law in cyberspace. Stanford Law Review, 48(5), 1367-1402.

Jones, H. (2009). Policy-making as discourse: A review of recent research-to-policy literature (Joint IKM Emergent-ODI Working Paper No. 5). Retrieved from IKM Emergent Website: http://www.odi.org.uk/resources/details.asp?id=2431\&title=policy-as-discourse

Karvalics, L. Z. (2007). Information Society - what is it exactly? (The meaning, history and conceptual framework of an expression) (Network for Teaching Information Society Coursebook). Retrieved from The Information Society and Trend Research Institute website: http://www.ittk.hu/netis/doc/ISCB_eng/o2_ZKL_final.pdf

Kindley, E. (2010, January 12). Creature of habitus: Latour on Bourdieu Pt. 1 [Academic blog]. Retrieved from

http://wehaveneverbeenblogging.blogspot.com/2009/12/creature-of-habitus-latour-on-bourdi eu.html

Knoke, D. (2004). The Sociopolitical Construction of National Policy Domains. In C. H. C. A. Henning \& C. Melbeck (Eds.), Interdisziplinäre Sozialforschung. Theorie und empirische Anwendungen: Festschrift für Franz Urban Pappi (pp.81-96). Frankfurt am Main, Germany: 
Campus.

Krick, E. (2015). Negotiated expertise in policy-making: How governments use hybrid advisory committees. Science and Public Policy, 42(4), 487-500. doi:10.1093/scipol/scuo69

Kubicek, H., Dutton, W. H., \& Williams, R. (Eds.). (1997). The social shaping of information superhighways: European and American roads to the information society. Frankfurt am Main, Germany: Campus

Lang, A. (2011). Interorganisatorische Koordination von Wirtschaftsverbänden: Relationale Dynamiken zwischen Hierarchie und Wettbewerb. PVS Politische Vierteljahresschrift, 52(1), 51-77. doi: 10.5771/o032-3470-2011-1-51

Latour, B. (2005). Reassembling the social: An introduction to Actor-Network-Theory. Clarendon lectures in management studies. Oxford, United Kingdom: Oxford University Press.

Latour, B. (2010). The Making of Law: An Ethnography of the Conseil d'Etat. Cambridge, United Kingdom: Polity Press.

Lessig, L. (2006). Code: And Other Laws of Cyberspace, Version 2.o. New York, NY: Basic Books.

Löblich, M., \& Wendelin, M. (2012). ICT policy activism on a national level: Ideas, resources and strategies of German civil society in governance processes. New Media \& Society, 14(6), 899-915. doi:10.1177/1461444811432427

Lynggaard, K. (2007). The institutional construction of a policy field: A discursive institutional perspective on change within the common agricultural policy. Journal of European Public Policy, 14(2), 293-312. doi:10.1080/13501760601122670

Marres, N. (2007). The Issues Deserve More Credit: Pragmatist Contributions to the Study of Public Involvement in Controversy. Social Studies of Science, 37(5), 759-780.

doi:10.1177/0306312706077367

Massey, E., \& Huitema, D. (2013). The emergence of climate change adaptation as a policy field: The case of England. Regional Environmental Change, 13(2), 341-352. doi:10.1007/s10113012-0341-2

Maurer, T., Morgus, R., Skierka, I., \& Hohmann, M. Technological Sovereignty: Missing the Point?: An Analysis of European Proposals after June 5, 2013. Retrieved from Global Public Policy Institute website:

http://www.gppi.net/fileadmin/user_upload/media/pub/2014/Maurer-et-al_2014_Tech-Sove reignty-Europe.pdf

Mayntz, R. (2001). Zur Selektivität der steuerungstheoretischen Perspektive (MPIfG Working Paper 01/2). Retrieved from Econstor website:

https://www.econstor.eu/bitstream/10419/44267/1/644382651.pdf

Meister, A. (2015). Geheime Kommunikation: BSI programmierte und arbeitete aktiv am Staatstrojaner, streitet aber Zusammenarbeit ab [blog]. Retrieved from:

https://netzpolitik.org/2015/geheime-kommunikation-bsi-

programmierte-und-arbeitete-aktivam-staatstrojaner-streitet-aber-zusammenarbeit-ab/. 
Zugegriffen: 25.01.2016.

Milliken, J. (1999). The Study of Discourse in International Relations: A Critique of Research and Methods. European Journal of International Relations, 5(2), 225-254. doi: $10.1177 / 1354066199005002003$

Moore, N. (1998). Policies for an information society. Aslib Proceedings, 5o(1), 20-24. doi:10.1108/ebo51478

Mueller, M. L. (2010). Networks and states: The global politics of Internet governance. Information revolution and global politics. Cambridge, MA: MIT Press.

Nelson, L. C. (2014). Bourdieu and Latour in STS: 'Let's leave aside all the facts for a while' (Master Thesis). The University of British Columbia, Vancouver, Canada. Retrieved from University of British Columbia website:

https://open.library.ubc.ca/cIRcle/collections/ubctheses/24/items/1.0166057

Nimmo, R. (2011). Actor-network theory and methodology: social research in a more-thanhuman world. Methodological Innovations Online, 6(3), 108-119. doi:10.4256/mio.2011.010

Pelizza, A., \& Hoppe, R. (2015). Birth of a Failure: Consequences of Framing ICT Projects for the Centralization of Inter-Departmental Relations. Administration \& Society. Advance online publication. doi: 10.1177/0095399715598343

Phillips, N., Lawrence, T. B., \& Hardy, C. (2004). Discourse and Institutions. The Academy of Management Review, 29(4), 635-652. Retrieved from http://www.jstor.org/stable/20159075

Prior, N. (2008). Putting a Glitch in the Field: Bourdieu, Actor Network Theory and Contemporary Music. Cultural Sociology, 3(2), 301-319. doi: 10.1177/1749975508095614

Sabatier, P. A. (1998). The advocacy coalition framework: Revisions and relevance for Europe. Journal of European Public Policy, 5(1), 98-130. doi:10.1080/13501768880000051

Schmidt, V. A. (2008). Discursive Institutionalism: The Explanatory Power of Ideas and Discourse. Annual Review of Political Science, 11(1), 303-326.

doi:10.1146/annurev.polisci.11.060606.135342

Schmidt, V. A. (2010). Taking ideas and discourse seriously: Explaining change through discursive institutionalism as the fourth 'new institutionalism'. European Political Science Review, 2(01), 1. doi:10.1017/S175577390999021X

Schmidt, V.A., \& Radaelli, C. M. (2004). Policy Change and Discourse in Europe: Conceptual and Methodological Issues. West European Politics, 27(2), 183-210.

Scholz, S. (2004). Internet-Politik in Deutschland: Vom Mythos der Unregulierbarkeit. Münster, Germany: Lit.

Schulze, M. (2016). (Un)Sicherheit hinter dem Bildschirm: Die Versicherheitlichung des Internets. In S. Fischer \& C. Masala (Eds.), Innere Sicherheit nach 9/11. Sicherheitsbedrohungen und (immer) neue Sicherheitsmaßnahmen? (pp. 165-185). Wiesbaden, Germany: Springer VS.

Scott, W. R. (2014). Institutions and organizations: Ideas, interests, and identities (Fourth 
edition). Los Angeles, CA: SAGE.

Special Committee 2000. (1999). Investigating the Impact of the Year 2000 Problem (No. S. Prt. 106-10). Retrieved from The United States Senate website:

https://www.gpo.gov/fdsys/pkg/GPO-CPRT-106sprt10/pdf/GPO-CPRT-106sprt10.pdf

Staatshandbuch Bund: Handbuch der Behörden mit Aufgabenbeschreibungen und Adressen. (1995 - 2014). Köln: Carl Heymanns.

Swartz, David. 1997. Culture \& power: The sociology of Pierre Bourdieu. Chicago: University of Chicago Press.

Thorein, T. (1997). Telekommunikationspolitik in Deutschland: Liberalisierung und Reregulierung. Wiesbaden, Germany: Deutscher Universitätsverlag.

Thornton, P. H., Ocasio, W., \& Lounsbury, M. (2012). The institutional logics perspective: A new approach to culture, structure and process. Oxford, United Kingdom: Oxford University Press.

van Audenhove, L., Burgelman, J.-C., Cammaerts, B., \& Nulens, G. (2003). Discourse and reality in international information society policy: The dominant scenario and its application in the developing world. Communicatio, 29(1-2), 79-113. doi:10.1080/02500160308538022

van Vugt, G. (2016). The Killer Idea: How Some Gunslinging Anarchists Held Freedom of Speech at Gunpoint. In B. van den Berg, S. van der Hof, \& E. Kosta (Eds.), Information Technology and Law Series: Vol. 26. 3D Printing. Legal, Philosophical and Economic Dimensions (1st ed., Vol. 26, pp.117-134). The Hague, The Netherlands: T.M.C. Asser Press.

Wu, T. (2010). Is Internet Exceptionalism Dead? In B. Szoka, A. Marcus, J. Zittrain, Y. Benkler, \& J. G. Palfrey (Eds.), The next digital decade. Essays on the future of the internet (pp.179-188). Washington, DC: TechFreedom.

\section{FOOTNOTES}

1. In addition, the essay contributes to theoretical and empirical research interested in the emergence of policy regimes (Jochim \& May, 2010; Braman, 2004). Although all authors share theoretical and conceptual ideas, the literature on the emergence of policy fields and regimes appears rather fragmented and lacks systematic methodological reflections.

2. Besides the growing number of academic publications on internet policy, this interest is reflected in a multitude of internet policy-related mapping platforms and capacity building programmes, such as the recently launched Global Internet Policy Observatory (GIPO), an online platform designed for information collection, analysis and sharing around internet policies in Europe and beyond. A comprehensive but non-exhaustive list of the different and often overlapping internet policy mapping initiatives is provided by the GovLab.

3. The acknowledgment that certain internet-related issues are effectively regulated by national governments is opposed to the belief in 'internet exceptionalism', which dominated the early days of the internet. It consisted in the idea that the internet, unlike earlier communication networks, would prove impossible to control or regulate, except through digital code. For more details and criticism of the exceptionalism argument, see Lessig (2006, pp.31ff) and Wu (2010).

4. These findings result from small case studies conducted by the Internet policy project group 
at the Berlin Social Science Center (WZB) in preparation of a larger international comparison.

5. More broadly, our conceptual approach is inspired by policy field definitions provided by other authors, such as Böcher and Töller (2012), Lynggaard (2007) and Sabatier (1998).

6. Despite a certain degree of heterogeneity among internet activists in Germany, Löblich and Wendelin identify a community that is united by a shared interest in digital technology, strong political awareness of related risks and challenges, a certain discontent with the 'political establishment' and a common call for internet freedom (2012, pp.905f).

7. Dobusch identifies three waves of civil society engagement in the German internet policy landscape since the 1980 s. In 2014, he counts about 13 main civil society groups that are actively involved in internet policy debates (2014, pp.5ff).

8. The two most important agencies involved in internet policy are the Federal Office for Information Security (Bundesamt für Sicherheit in der Informationstechnik), established in 1991, and the Federal Network Agency (Bundesnetzagentur), created in 1998.

9. The system of business associations in the German IT sector started to develop from 1988 onwards and consists today of about fifteen main actors (Lang, 2011).

10. Traditional policy analysis is often criticised for having a problem-solving bias (Mayntz, 2001), as it understands policymaking as a process of objective problem solving. We follow this criticism by arguing that policy problems and their solutions are always socially constructed.

11. This understanding is an extension of the basic definition given by Maarten Hajer (1993, p.45) and is inspired by the reflections of Fischer \& Forester (1993), Fischer \& Gottweis (2012), Milliken (1999). For an overview on the different understandings of the term 'discourse' in relation to policy and policymaking, see Gasper and Apthorpe (1996, pp. 2ff).

12. While formal institutions encompass, for instance, rules, procedures and organisational structures, informal institutions consist of norms, patterns of belief and behaviour, worldviews and other loose but persistent structures that impact on the way actors think and act. In a policy field, these institutions provide the frame in which policy debates take place: 'By defining who is able to participate in different decision-making processes, shape actors' strategies, and influence what actors believe to be possible and desirable, these rules structure the policy process.' (Jones, 2009, p. 13)

13. It would go beyond the focus of this research essay to discuss the complex relationship of discourse and institutions in great detail. In the last decade, the neo-institutionalist stream of 'discursive institutionalism' provided the most fundamental reflections on this question and hence constitutes another theory that inspired our analytical approach (Schmidt, 2008; 2010). See also Phillips et al. (2004).

14. Since some original STS authors have positioned themselves against Bourdieu and his social theory (Callon, 1987; Latour, 2005), many authors have discussed the divergences between field theory and actor-network theory and their possible combination (e.g. Prior, 2008; Kindley, 2010; Nelson, 2014). The two theoretical streams share elements as they both emphasise the relational nature of the social and criticise individualistic, rational choice or deterministic approaches (Bigo, 2011, p. 236). We believe that their combination is fruitful, because the field approach serves to address the linkages and structures at the meso-level and their temporal continuity or stability while selected STS tools allow us to describe the effects of struggles and 
inscriptions on the micro-level and the material traces they leave.

15. The essay does not propose a strict implementation of an STS approach but, instead, the use of selected conceptual ideas from the STS toolbox. Besides the concept of inscription, the essay is inspired, for instance, by the postulation to follow actors in order to retrace their processes of social ordering and the establishment of temporary power positions. Particularly useful for scrutinising the internet policy field is STS's enlarged understanding of actors that grants agency not only to humans but also to material objects and semantics (Bijker \& Law, 1994, p. 449; Latour, 2005, p. 465). This makes it possible to account for the influence of digital technology in a non-deterministic way. However, due to the space restrictions, this short essay does not allow us to elaborate on these aspects in more detail.

16. During our period of investigation (1995-2016), the first two examples show the earliest instances of discourse institutionalisation we can observe in the organisational charts of the Federal Ministry of the Interior and the Federal Ministry for Economic Affairs. We added the third example to illustrate a late instance of discourse institutionalisation in reaction to the same public debate in both ministries.

17. The Digital Agenda identifies several strategic areas or activities that should contribute to bringing Germany to the forefront of digital development, including digital economy and innovation, security and trust, and digital infrastructure. The Ministry of the Interior and the Ministry for Economic Affairs share the responsibility for coordinating and implementing the Digital Agenda with a third ministry, the Federal Ministry of Transport and Digital Infrastructure. As the latter only recently (2014) received competencies for digital infrastructure, in particular regarding broadband deployment policy, it does not have a long history of developing competencies for internet policy. Therefore, we did not include it in the selected empirical examples presented in this essay.

18. We used a historiographical approach for the analysis of the organisational charts that visualises the development of specific organisational units within a ministry as a chronological sequence. These timelines are based on public data available in 'Bund transparent' (1995-2015) and 'Staatshandbuch Bund' (1995-2015). Besides giving important indications about the inscription of discourses and the institutionalisation of competences, the findings gained from the analysis of the charts also served to prepare the interviews.

19. The interviews were conducted in 2015 by different members of the WZB Internet policy project group. Since unauthorised quotations from the interviews are not permitted, we avoid direct quotes in the essay. Instead, we use the interviews only as background information and for indirect, anonymous references. Up until 2016, we conducted eight interviews with civil servants who have witnessed the emergence of internet policy in the two ministries from which we draw the example for this research essay (the Federal Ministry of the Interior and the Federal Ministry for Economic Affairs).

20. The debate on the information society started as early as the 1960s, when several authors in Japan and the United States began to reflect on the effects of an economy increasingly driven by information and knowledge rather than industrial and agricultural work (Karvalics, 2007). But it was only after the US launched its National Information Infrastructure initiative in 1993 that many governments adopted similar policies initiatives that all shared some core ideas which seem characteristic of the information society discourse: a techno-deterministic perspective on digital technology and the conviction that technological progress would automatically lead to economic and societal prosperity (van Audenhove, Burgelman, Cammaerts, \& Nulens, 2003, 
p.82).

21. In the mid-1990s, the discourse was also inscribed in two advisory committees: the Petersberger Kreis and the Council for Research, Technology and Innovation. According to our interviewees, the latter also led to the creation of new regulatory competencies within the Federal Ministry of Education and Research, which later, in 1999, were integrated into the Federal Ministry for Economic Affairs.

22. Industrial policy can be summarised as 'a nation's declared, official, total effort to influence sectoral development and, thus, national industrial portfolio' (Graham, 1994, p.3).

23. Note from the editor: a previous version of this paper mistakenly mentioned Roman Herzog as being the then Minister of Economic Affairs, instead of Günter Rexrodt. We replaced the initial name with the correct one on 2 May 2017. All our apologies for not picking up the mistake in our fact-check at the time of publication.

24. The 'Info 2000' strategy paper was a result of a coordinated effort between five ministries, with the Federal Ministry for Economic Affairs and its working group taking the lead (Thorein, 1997, pp. 58ff). In addition, the paper was influenced by ideas developed in the context of the Petersberger Kreis and the Council for Research, Technology and Innovation (BMWi,1996), both policy forums in which the Federal Ministry for Economic Affairs was involved.

25. The global crisis scenarios around the Y2Y bug led to the establishment of temporary task forces and crisis committees at the national and supranational levels (e.g. de Borchgrave \& Lanz, 1999), including in the German Ministry of the Interior.

26. German ministries are generally organised along line organisational structures. A division (Abteilung), led by the division's director, is composed by subdivisions (Unterabteilungen) with several sections (Referate) as the smallest unit (Hustedt and Tiessen, 2006, p.25). In contrast to the hierarchical line organisation, in few cases competencies are organised as a staff (Stab) which directly reports to the state secretaries and the minister.

27. The relationship between public discourse and changes within the public administration is rarely studied. While some authors study the media framing of governmental IT system failures and their impact on the organisation of the government's operational IT management (Pelizza \& Hoppe, 2015), we focus on role of public discourses for the emergence of internet-related responsibilities within ministries.

28. The 'crypto debate'-or 'crypto war' as it is often called-refers to the struggle between governments and intelligence agencies on the one hand and civil society and IT companies on the other hand, over the question whether the export and individual use of cryptography should be limited in order to allow for decryption for the purpose of national security. See, for instance, Giacomello (2008, pp.26ff). A recent variation on this debate is the conflict between Apple and the US Federal Bureau of Investigation (FBI) over the decryption of an iPhone that could potentially contain evidence about a mass shooting.

29. One example is the controversy about the Staatstrojaner, a government spyware developed for 'source-telecommunication surveillance' by the Federal Criminal Police Office (Bundeskriminalamt). Actors from civil society, namely the Chaos Computer Club and the blog netzpolitik.org, and politicians from Germany's opposition parties criticise the use of the trojan in general, mainly for privacy reasons, and the involvement of the Federal Office for Information 
Security (BSI) in the software's development (see, for instance, Meister, 2015).

30. The question of technological sovereignty was not entirely new to the German public since already back in 2010 the then Minister of the Interior had promoted this concept in a programmatic paper on internet policy, in which he already linked it to the importance of a strong national IT sector (de Maizière, 2010, p.4). An interviewee pointed out that de Maizière's use of the concept inspired the idea to use the the term 'digital sovereignty' (the full title of the unit is 'Economic Questions of the Digital Agenda and Societal Developments, Digital Sovereignty') for the new responsibilities created within the ministry.

31. The policy paper 'Guide Rails of Digital Sovereignty' (Leitplanken der digitalen Souveränität) highlights three topics: efficient and secure infrastructure, mastery of key competencies and technologies, and a framework for digital sovereignty open to innovation. It was prepared by the Ministry for Economic Affairs in cooperation with a group of experts in the context of the national IT Summit. These kinds of national summits are governance instruments best described as '[h]ybrid advisory committees that are set up by governments and incorporate societal representatives alongside scholars and state agents [...]' (Krick, 2015, p. 487). 